\title{
MINIMIZING RESIDUAL STAND DAMAGE AND FELLING COS'T USING LOWEST POSSIBLE FELLING TECHNIQUE (A case study in one logging company in West Kalimantan)
}

\author{
Sona Suhartana and Krisdianto ${ }^{1}$
}

\begin{abstract}
The implementation of felling technique in logging companies is not yet carried out efficiently and appropriately. Study on the lowest possible felling technique (LPFT) is considered to be important to reduce residual stand damage and felling cost. This study was carried out in a logging company in West Kalimantan in 2004. The aim of this study was to determine the effect of LPFT on residual stand damage and felling cost. Data collected in this research include: residual stand damage, working time, timber volume, productivity, efficiency, stump height and felling cost. Two categories data were analyzed with respect to their possible differences using T-test. The result showed that the implementation of LPFT was more advantage impact compared to that of conventional felling technique, which is indicated by the following factors: (1) Trees damage decreased $2.96 \%$; (2) Poles damage decreased $4.75 \%$; (3) Felling productivity decreased $17.16 \%$; (4) Felling efficiency increased approximately $3.2 \%$; (5) Felling cost increased about Rp $327.07 / \mathrm{m}^{3}$; and (6) in average stump height was $40.60 \mathrm{~cm}$ lower.
\end{abstract}

Keywords: felling technique, residual stand damage, increasing production, natural forest product

\section{INTRODUCTION}

Tree felling is one of logging activity which is the beginning of timber utilization process. Tree felling is defined as a process to bring down tree and cut it into appropriate size fớr further use. In natural forest, this activity is conducted using selective cutting system.

Welburn (1981) states that selective cutting technique and cutting direction create many problems in tree felling. An appropriate felling technique and felling tool should be considered as major factors to minimize resource waste. Generally, the technique carried out by chainsaw operator is based on his habit and ease without considering work standard. The most frequent error made is inappropriate cutting preparation (height, shape and size).

Generally, mechanical tree felling results in highest rate of productivity. However, this technique often causes residual stand damage and forest floor damage as a result of mechanical tool operation, hasty work and inappropriate method. The damage is also found in timber, which results in waste of timber in felling plot. To avoid unexpected result, a technique that accommodates the economics and ecology needs has to be implemented. The efficient and effective technique used will determine the overall efficiency of timber utilization. In natural forest, there are inaccuracies that result in inefficient activity

${ }^{1}$ Forest Products Technology Research and Development Center, Bogor 
(Holmes et al., 1999 and Grulois, 2000). Based on field review, Suhartana (2001) found at least two most important factors that need to be evaluated. They are residual stand damage and stump height left in the field.

The aim of this study was to determine the effect of Lowest Possible Felling Technique (LPFT) on residual stand damage, working time, timber volume, productivity, efficiency, stump height and felling cost. The implementation of this technique was analyzed in order to minimize residual stand damage and felling cost of logging in natural forest.

\section{METHODOLOGY}

\section{A. Time and Location}

This research was conducted in June 2004 in the work area of PT. Suka Jaya Makmur Logging Concession. This logging concession was located in the area of Forest District of Ketapang, Forest Service of West Kalimantan Province. Based on government administration, this logging concession was a part of Ketapang District, West Kalimantan Province.

The majority of research areas had field slope of between $9-21 \%$ with elevation of 50 350 meter above sea level. Based on Schmidt and Ferguson climate classification, the research area was type A with rainfall of $2,998 \mathrm{~mm} /$ year. The type of soil was red yellow podzolic. The area was about $62 \%$ dominated by meranti (Shorea spp.). Tree density was about 141-162 trees/ha. Most trees had bole. Shrub in average has intermediate density. The tools used for timber harvesting were the STIHL chainsaw type 070 for tree felling and wood cutting, Caterpillar tractor type D7G for timber skidding, Renault truck type 400 for transportation, and Komatsu excavator type PC200 for timber loading and unloading.

\section{B. Research Object, Material and Tool}

The object of this research was felling plot that is included in the Company Annual Work Plan 2004. The material and tool used in this research are paint, paintbrush, plastic rope, phi-band measurement, gauge, stopwatch, compass and chainsaw (STIHL type 070).

\section{Research Procedure}

The stages of this research include:

1. Determine one felling plot for tree felling.

2. From the felling plot, 8 (eight) measuring plots were established with the size of $100 \mathrm{~m}$ by $100 \mathrm{~m}$ : 4 plots for lowest possible felling technique and 4 plots for conventional felling technique.

3. Felling the tree with lowest possible felling technique and conventional felling technique with repetition of 24 and 28 trees respectively.

4. Parameter measurement:

a. Residual stand damage: number of original trees, damaged and undamaged trees. 
b. Felling productivity: felling time and volume of sawn timber.

c. Timber utilization efficiency: bottom diameter, top diameter, tree height and log length.

d. Felling cost: all expenses related to felling activity, which include the expenses of fuel, oil, wages, productivity, depreciation, maintenance, interest, insurance and tax.

e. General data such as field general condition, company general condition and secondary data taken from company profile and interview with employees.

Conventional felling technique in this research was felling technique that was usually used by local operator without direction from researcher. Lowest possible felling technique was the felling technique that leave stump as low as possible.

\section{Data Processing}

Field data that include residual stand damage, felling productivity and timber utilization effectiveness were presented in the form of tabulation.

1. Tree damage:

$$
\mathrm{TD}=\frac{\mathrm{DT}}{\mathrm{OT}-\mathrm{FT}} \times 100 \%
$$

Where: TD : Tree damage (\%)

DT : Damaged trees (trees/ha)

OT : Number of trees before felling process (trees/ha)

FT : Felled Trees (trees/ha)

2: Pole damage:

$$
\mathrm{PD}=\frac{\mathrm{DS}}{\mathrm{OP}} \times 100 \%
$$

Where: PD :Pole damage (\%)

DS :Damaged poles (number of $\log / \mathrm{ha}$ )

OP : Number of poles before felling process (number of $\log / \mathrm{ha}$ )

3. Felling productivity:

$$
\mathrm{FP}=\frac{\mathrm{TV}}{\mathrm{FT}} ; \mathrm{TV}=0.25 ; \Pi \mathrm{D} 2 \mathrm{~L} ; \mathrm{D}=0.5(\mathrm{Db}+\mathrm{Dt})
$$

Where: FP : Felling productivity $\left(\mathrm{m}^{3} /\right.$ hour $)$

TV :Felled trees volume $\left(\mathrm{m}^{3}\right)$

FT :Felling time (hour) 

П :3.1416
L : Length of log
D : Average diameter
$\mathrm{Db}:$ : Bottom diameter
Dt :Top diameter

4. Timber utilization efficiency:

$$
\begin{aligned}
& \mathrm{UE}=\frac{\mathrm{Vt}}{\mathrm{Va}} \\
& \text { Where: } \begin{array}{ll}
\mathrm{UE} & : \text { Utilization efficiency }(\%) \\
\mathrm{Vt} & : \text { Volume of trees taken }\left(\mathrm{m}^{3}\right) \\
& \text { Va } \quad: \text { Volume of trees that can be used }\left(\mathrm{m}^{3}\right)
\end{array}
\end{aligned}
$$

5. Felling Cost:

$$
\begin{aligned}
& F C=\frac{E d+E i s+E i t+E t+E f+E o+E m+E w}{F P} \\
& \mathrm{Ed}=\frac{\mathrm{P}}{1,000 \text { hour }} \quad \text { Eis }=\frac{\mathrm{P} \times 0.6 \times 3 \%}{1,000 \text { hour }} \quad \text { Eit }=\frac{\mathrm{P} \times 0.6 \times 18 \%}{1,000 \text { hour }} \\
& \mathrm{Et}=\frac{\mathrm{P} \times 0.6 \times 2 \%}{1,000 \text { hour }} \quad \mathrm{Ef}=0.20 \times \mathrm{P} \times 0.54 \times \mathrm{FP} \\
& \mathrm{Eo}=0.1 \mathrm{Ef} \quad \mathrm{Em}=1.0 \mathrm{x} \mathrm{Ed}
\end{aligned}
$$

Where: FC : Felling cost $\left(\mathrm{Rp} / \mathrm{m}^{3}\right)$

Ed : Depreciation expenses $\left(\mathrm{Rp} / \mathrm{m}^{3}\right)$

Eis : Insurance expenses (Rp/hour)

Eit : Interest expenses (Rp/hour)

Et : Tax expenses (Rp/hour)

Ef : Fuel expenses (Rp/hour)

FP : Fuel price ( $\mathrm{Rp} /$ liter)

Eo : Oil expenses (Rp/hour)

Em : Maintenance and repair expenses (Rp/hour)

Ew : Wages expenses (Rp/hour)

FP : Felling productivity $\left(\mathrm{m}^{3} /\right.$ hour $)$

$\mathrm{P} \quad$ : Tool price $(\mathrm{Rp})$

FP : Felling productivity $\left(\mathrm{m}^{3} /\right.$ hour $)$

To determine suggested technique, two felling techniques would be compared based on residual stand damage, felling productivity, timber utilization efficiency and felling cost, using T-test (Prajitno, 1981) 


\section{RESULT AND DISCUSSION}

\section{A. Tree Damage}

Tree damage due to felling activity using both conventional felling technique and lowest possible felling technique is shown in Table 1.

Table 1. Tree damage caused by tree felling

\begin{tabular}{|c|c|c|c|c|c|c|c|c|c|}
\hline \multirow[t]{2}{*}{ Plot } & \multirow{2}{*}{$\begin{array}{c}\text { Felled } \\
\text { trees } \\
\text { (trees/ha) }\end{array}$} & \multicolumn{3}{|c|}{$\begin{array}{l}\text { Trees before felling } \\
\text { (trees/ha) }\end{array}$} & \multicolumn{3}{|c|}{$\begin{array}{l}\text { Damaged trees } \\
\text { (trees/ha) }\end{array}$} & \multirow{2}{*}{$\begin{array}{l}\text { Slope } \\
(\%)\end{array}$} & \multirow{2}{*}{$\begin{array}{c}\text { Damaged } \\
\text { trees } \\
(\%)\end{array}$} \\
\hline & & $\Sigma$ & C & $\mathrm{NC}$ & $\Sigma$ & C & NC & & \\
\hline
\end{tabular}

a. Conventional Felling Technique (CFT)

\begin{tabular}{|c|c|c|c|c|c|c|c|c|c|}
\hline 1 & 6 & 155 & 135 & 20 & 10 & 8 & 2 & 13 & 6.71 \\
\hline 2 & 9 & 147 & 122 & 25 & 12 & 9 & 3 & 21 & 8.69 \\
\hline 3 & 7 & 162 & 139 & 23 & 11 & 9 & 2 & 18 & 7.10 \\
\hline 4 & 6 & 141 & 126 & 15 & 9 & 8 & 1 & 9 & 6.67 \\
\hline$\Sigma$ & 28 & 605 & 522 & 83 & 42 & 34 & 8 & 61 & 29.17 \\
\hline $\mathrm{M}$ & 7.00 & 151.25 & 130.50 & 20.75 & 10.50 & 8.50 & 2.00 & 15.30 & 7.29 \\
\hline $\mathrm{SD}$ & 1.41 & 9.18 & 7.85 & 4.35 & 1.29 & 0.57 & 0.82 & 5.32 & 0.95 \\
\hline $\begin{array}{l}\text { CV } \\
(\%)\end{array}$ & 20.10 & 6.10 & 6.00 & 20.90 & 12.30 & 6.70 & 41.00 & 34.80 & 13.00 \\
\hline & & & & & & & & & \\
\hline
\end{tabular}

b. Lowest Possible Felling Technique (LPFT)

\begin{tabular}{|c|c|l|r|r|r|r|r|r|r|}
\hline 1 & 7 & 152 & 122 & 30 & 6 & 5 & 1 & 12 & 4.14 \\
\hline 2 & 5 & 125 & 95 & 30 & 2 & 2 & 0 & 14 & 4.17 \\
\hline 3 & 8 & 153 & 128 & 25 & 14 & 12 & 2 & 17 & 5.52 \\
\hline 4 & 4 & 119 & 96 & 23 & 5 & 4 & 1 & 10 & 3.48 \\
\hline$\Sigma$ & 24 & 549 & 441 & 108 & 27 & 23 & 4 & 53 & 17.31 \\
\hline $\mathrm{M}$ & 6.00 & 137.30 & 110.30 & 27.00 & 6.75 & 5.75 & 1.00 & 13.25 & 4.33 \\
\hline $\mathrm{SD}$ & 1.83 & 17.78 & 17.21 & 3.56 & 5.12 & 4.35 & 0.82 & 2.99 & 0.86 \\
\hline $\begin{array}{c}\mathrm{CV} \\
(\%)\end{array}$ & 30.5 & 12.90 & 15.60 & 13.20 & 75.80 & 75.60 & 82.00 & 22.60 & 19.9 \\
\hline
\end{tabular}

Remarks: $\Sigma=$ Sum; $M=$ Mean; $S D=$ Standard Deviation; $C V=$ Coefficient of Variation; $\mathrm{C}=$ Commercial $; \mathrm{NC}=$ Non-Commercial

Table 1 shows that the average tree damage caused by conventional felling technique is $7.29 \%$. This means cutting down 7 trees/ha results in damage of about $7.29 \% \times$ (151.25-7) trees $/$ ha $=10.5$ trees $/$ ha. Whereas, the average of tree with diameter of $20 \mathrm{~cm}$ or above, which is in good condition after felling process is $(100-7.29) \% \mathrm{x}(151.25-7)$ trees $/ \mathrm{ha}=133.7$ trees/ha. More than half ( 115 trees/ha) of these good trees are commercial trees. 
On the other hand, tree damage caused by lowest possible felling technique is $4.33 \%$. This means cutting down 6 trees/ha causes the damage of about $4.33 \% \mathrm{x}(137.3-6)$ trees $/ \mathrm{ha}=$ 5.7 trees/ha. Whereas, the average of tree with diameter of $20 \mathrm{~cm}$ or above, which is in good condition after felling process is $(100-4.33) \% \mathrm{x}(137.3-6)$ trees $/$ ha $=125.6$ trees $/$ ha. More than half (98.6 trees/ ha) of these good trees are commercial trees.

Based on data in Table 1, it can be concluded that the average tree damage caused by lowest possible felling technique is less than that by conventional felling technique, with the difference of $2.96 \%$. This conclusion is strengthened by the result of T-test of $10.864 * *$ that is greater than t-table $99 \%=3.707$. This means that the differences of tree damage in such two techniques are highly significant.

The implementation of lowest possible felling technique can reduce tree damage about $2.96 \%$. With the average timber production of $59,900 \mathrm{~m}^{3}$, and exploitation factor as well as corrective number of 0.49 , the company can increase the efficiency about $2.96 \% \times 59,900 \mathrm{~m}^{3} \mathrm{x}$ $0.49=868.79 \mathrm{~m}^{3}$. Assuming the timber price in the market is Rp 550,000 $\mathrm{m}^{3}$, the company can save up to $868.79 \mathrm{~m}^{3} \times \mathrm{Rp} 550,000 / \mathrm{m}^{3}=\mathrm{Rp} 477,834,500$ by implementing the lowest possible felling technique. Considering the benefits, it is promising to implement lowest possible felling technique.

\section{B. Poles Damage}

Pole damage due to felling activity using conventional felling technique and lowest possible felling technique is shown in Table 2.

Table 2. Poles damage caused by tree felling

\begin{tabular}{|c|c|c|c|c|c|c|c|c|}
\hline \multirow{3}{*}{ Plot } & \multicolumn{4}{|c|}{ Lowest possible felling technique } & \multicolumn{4}{|c|}{ Conventional felling technique } \\
\hline & \multirow{2}{*}{$\begin{array}{c}\text { Before felling } \\
\text { (tree/ha) }\end{array}$} & \multicolumn{2}{|c|}{ Pole damage } & \multirow{2}{*}{ Slope } & \multirow{2}{*}{$\begin{array}{c}\text { Before felling } \\
\text { (tree/ha) }\end{array}$} & \multicolumn{2}{|c|}{ Pole damage } & \multirow{2}{*}{ Slope } \\
\hline & & Poles/ha & $\%$ & & & Poles/ha & $\%$ & \\
\hline 1 & 124 & 11 & 8.87 & 12 & 164 & 21 & 12.80 & 12 \\
\hline 2 & 143 & 9 & 6.29 & 14 & 149 & 16 & 10.74 & 21 \\
\hline 3 & 161 & 13 & 8.07 & 17 & 169 & 20 & 11.83 & 18 \\
\hline 4 & 128 & 7 & 5.47 & 10 & 146 & 18 & 12.33 & 9 \\
\hline$\Sigma$ & 556 & 40 & 28.7 & 53 & 628 & 75 & 47.70 & 61 \\
\hline M & 139 & 10 & 7.18 & 13.25 & 157 & 18.75 & 11.925 & 15.25 \\
\hline SD & 16.79 & 2.58 & 1.57 & 2.99 & 11.22 & 2.22 & 0.88 & 5.32 \\
\hline $\begin{array}{l}\text { CV } \\
(\%)\end{array}$ & 12.1 & 25.8 & 21.9 & 22.6 & 7.1 & 7.1 & 7.4 & 34.9 \\
\hline
\end{tabular}

Remarks: $\Sigma=$ Sum; $M=$ Mean; $S D=$ Standard Deviation; $C V=$ Coefficient of Variation 
Table 2 shows that the average pole damage due to tree felling using lowest possible felling technique $(7.18 \%)$ is less than that of using conventional techniques $(11.93 \%)$ with the difference of $4.75 \%$. The T-test result is $5.865^{* *}(\mathrm{t}$-table $99 \%=3.707)$, which indicates that the differences of pole damage in both techniques is very significant.

\section{Felling Productivity}

The felling productivity using both lowest possible felling technique and conventional technique is presented in Table 3 .

Table 3. The average productivity and efficiency

\begin{tabular}{|c|c|c|c|c|c|c|}
\hline Unit & $\begin{array}{c}\text { Log volume } \\
\left(\mathrm{m}^{3}\right)\end{array}$ & $\begin{array}{c}\text { Waste } \\
\text { volume } \\
\left(\mathrm{m}^{3}\right)\end{array}$ & $\begin{array}{c}\text { Felling } \\
\text { time } \\
\text { (hour })\end{array}$ & $\begin{array}{c}\text { Productivity } \\
\left(\mathrm{m}^{3} / \text { hour }\right)\end{array}$ & $\begin{array}{c}\text { Efficiency } \\
(\%)\end{array}$ & $\begin{array}{c}\text { Stump height } \\
(\mathrm{cm})\end{array}$ \\
\hline \multicolumn{7}{|c|}{ a. The average productivity and efficiency of conventional felling technique $(\mathrm{N}=28)$} \\
\hline R & $2.830-12.010$ & $0.184-0.705$ & $0.083-0.522$ & $19.012-36.161$ & $92.2-96.2$ & $52.15-120.05$ \\
\hline M & 5.955 & 0.338 & 0.246 & 25.704 & 94.4 & 86.55 \\
\hline SD & 2.513 & 0.137 & 0.128 & 4.587 & 1.07 & 16.06 \\
\hline CV & 0.422 & 0.405 & 0.520 & 0.178 & 0.11 & 0.186 \\
\hline b. The average productivity and efficiency of lowest possible felling technique $(\mathrm{N}=24)$ \\
\hline R & $4.440-12.980$ & $0.067-0.379$ & $0.154-0.516$ & $17.106-28.831$ & $94.4-98.8$ & $28.51-67.15$ \\
\hline M & 7.6342 & 0.177 & 0.361 & 21.294 & 97.6 & 40.60 \\
\hline SD & 2.585 & 0.085 & 0.108 & 3.697 & 1.24 & 9.73 \\
\hline CV & 0.339 & 0.480 & 0.299 & 0.174 & 0.130 & 23.9 \\
\hline
\end{tabular}

Remarks: $\mathrm{R}=$ Range; $\mathrm{M}=\mathrm{Mean} ; \mathrm{SD}=\mathrm{Standard}$ Deviation; $\mathrm{CV}=$ Coefficient of Variation; $\mathrm{N}=$ Number of replication

The highest productivity using lowest possible felling technique $\left(28,831 \mathrm{~m}^{3} /\right.$ hour $)$ is reached within felling time of 9 minutes 14 seconds and the volume of tree felled is $4.44 \mathrm{~m}^{3}$. The lowest productivity $\left(17.106 \mathrm{~m}^{3} /\right.$ hour $)$ is reached within felling time of 22 minutes 19 seconds and the volume of tree felled is $6.33 \mathrm{~m}^{3}$.

By using conventional felling technique, the highest productivity $\left(36.161 \mathrm{~m}^{3} /\right.$ hour $)$ is reached within felling time of 6 minutes 43 seconds and the volume of tree felled is $4.05 \mathrm{~m}^{3}$. The lowest productivity $\left(19.012 \mathrm{~m}^{3} /\right.$ hour $)$ is reached within felling time of 24 minutes 18 seconds and the volume of tree felled is $7.7 \mathrm{~m}^{3}$.

Table 3 indicates that the average felling productivity using lowest possible felling technique is less than of that using conventional felling technique, which is $21.294 \mathrm{~m}^{3} /$ hour and $25.704 \mathrm{~m}^{3} /$ hour respectively. This means the felling productivity difference is 4.41 $\mathrm{m}^{3}$ /hour or it can be said that the felling productivity of the lowest possible technique is about $17.16 \%$ less than that of conventional technique. The possible factor that affects the productivity is the felling time. In lowest possible felling technique, the preparation of back and felling cut requires more time as it has to be prepared correctly so that timber can be 
maximally utilized and the damage can be minimized. Therefore, the felling time become longer and the productivity become low. However, in long term, lowest possible felling technique would bring in more advantages, as it would provide more timber volume that can be utilized. Moreover, as the wages is paid based on the timber volume, not the felling time, the productivity in terms of felling time can be ignored. If the operators get used to applying lowest possible felling technique, it is expected that the productivity will increase.

\section{Stump Height}

The height of stump left in the field is presented in Table 3. The average stump height after using lowest possible felling technique $(40.6 \mathrm{~cm})$ is lower than that after using conventional felling technique $(88.05 \mathrm{~cm})$. The T-test result is of $45.999 * *$, which is greater than t-table $99 \%=2.682$. This means, considering the differences of stump height these two techniques are very significant. The waste amount from the stump will then affect the efficiency of timber utilization. The greater the utilized waste, the higher the efficiency of timber utilization.

\section{E. Timber Utilization Efficiency}

Table 3 also presents the result of felling efficiency measurement. The average timber utilization efficiency using conventional felling technique was only $94.4 \%$. Whereas, using lowest possible felling technique, the average timber utilization efficiency accounted for $97.6 \%$. The timber utilization efficiency is mostly affected by stump waste volume. From Table 3, it can be seen that the average stump waste volume of lowest possible felling technique and conventional felling technique is $0.338 \mathrm{~m}^{3}$ and $0.177 \mathrm{~m}^{3}$ respectively. This means the difference of stump waste volume is $0.161 \mathrm{~m}^{3} /$ tree. It can also be said that timber utilization efficiency of lowest possible felling technique is higher than that of conventional felling technique.

The measurement result of timber utilization efficiency also indicates that by implementing lowest possible felling technique, the utilization efficiency can be improved up to $3.2 \%$. Based on field data and quotation from company office, the average tree felled is 6.5 trees/ha with the average volume of $6.795 \mathrm{~m}^{3} /$ tree. The forest area planned for tree felled annually is $1,890 \mathrm{ha}$ with the production target of $59,902 \mathrm{~m}^{3}$ per year. With $3.2 \%$ timber utilization improvement, the company can benefit from production increase of $3.2 \% \mathrm{x}$ $59,902 \mathrm{~m}^{3}=1,916.861 \mathrm{~m}^{3} /$ year. Assuming the price of timber in the market is Rp $550,000 / \mathrm{m}^{3}$ and the reasonable profit of $20 \%\left(\mathrm{Rp} 110,000 / \mathrm{m}^{3}\right)$, the company is expected to gain more profit of $1,916.861 \mathrm{~m}^{3} \times \mathrm{Rp} 110,000 / \mathrm{m}^{3}=\mathrm{Rp} 210,855,040$ per year. Considering the benefits of lowest possible felling technique, it is promising to implement the technique.

\section{F. Felling Cost}

By measuring the productivity, purchasing and operational cost of STIHL chain saw type 070 for tree felling, the felling cost per $\mathrm{m}^{3}$ can be calculated. The tool purchasing and operational cost is as follows: 
1) Price per unit $=\operatorname{Rp} 6,500,000$

2) Fuel price $=\operatorname{Rp} 1,850 /$ litre

3) Expected life of tool $=1$ year $=1000$ hours

4) Insurance $=3 \% /$ year

5) Interest $=18 \% /$ year

6) $\operatorname{Tax}=2 \% /$ year

7) Operator and helper wages $=\operatorname{Rp} 200,000 /$ day

8) Work hour per day $=8$ hours

9) Machine power $=15 \mathrm{HP}$

From the above data, the expenses component can be calculated as follows:

\begin{tabular}{|c|c|c|c|}
\hline \multirow{2}{*}{ Depreciation Expenses } & \multirow{2}{*}{$=$} & $\operatorname{Rp} 6,500,000 \times 0.9$ & \multirow{2}{*}{$=\operatorname{Rp} 5,850 /$ hour } \\
\hline & & 1000 hours & \\
\hline \multirow[t]{2}{*}{ Insurance Expenses } & \multirow[t]{2}{*}{$=$} & $\operatorname{Rp} 6,500,000 \times 0.6 \times 3 \%$ & \multirow{2}{*}{$=\operatorname{Rp} 117 /$ hour } \\
\hline & & 1000 hours & \\
\hline \multirow{2}{*}{ Interest Expenses } & \multirow[t]{2}{*}{$=$} & $\operatorname{Rp} 6,500,000 \times 0.6 \times 18 \%$ & \multirow{2}{*}{$=\operatorname{Rp} 702 /$ hour } \\
\hline & & 1000 hours & \\
\hline \multirow{2}{*}{ Tax Expenses } & \multirow{2}{*}{$=$} & $\mathrm{Rp} 6,500,000 \times 0.6 \times 2 \%$ & \multirow{2}{*}{$=\operatorname{Rp} 78 /$ hour } \\
\hline & & 1000 hours & \\
\hline Fuel Expenses & $=$ & $0.20 \times 15 \times 0.54 \times \operatorname{Rp} 1,850$ & $=\mathrm{Rp} 2.97 /$ hour \\
\hline Oil Expenses & $=$ & $0.1 \times \operatorname{Rp} 2,997 /$ hour & $=\operatorname{Rp} 299.70 /$ hour \\
\hline Maintenance Expenses & $=$ & $1 \times \operatorname{Rp} 5,850 /$ hour & $=\operatorname{Rp} 5,850 /$ hour \\
\hline Wages Expenses & $=$ & Rp 200,000: 8 hour & $=\operatorname{Rp} 25,000 /$ hour \\
\hline Machine Expenses/hour & $=$ & Rp 40,594/hour & \\
\hline
\end{tabular}


Based on the above data, the felling cost of chain saw using conventional felling technique is $\mathrm{Rp} 40,594 /$ hour : $25.704 \mathrm{~m}^{3} /$ hour $=\mathrm{Rp} 1,579.29 / \mathrm{m}^{3}$. Whereas, using lowest possible felling technique the felling cost is $\mathrm{Rp} 40,241.02 /$ hour $: 21.294 \mathrm{~m}^{3} /$ hour $=\mathrm{Rp}$ $1,906.36 / \mathrm{m}^{3}$. This means the cost of lowest possible felling technique is more expensive as much as $\mathrm{Rp} 327.07 / \mathrm{m}^{3}$ than that of conventional felling technique. This result is different from the research result of Grulois (2000) on felling cost using chain saw in East Kalimantan. The average felling cost of conventional technique was $\mathrm{Rp} 1,170 / \mathrm{m}^{3}$, while the average felling cost of natural concern technique was $\mathrm{Rp} 850 / \mathrm{m}^{3}$. The difference between the felling cost of chain saw in this study and Grulois's study is affected by operator habit. In this research chain saw operator has not been familiar with lowest possible felling technique, so that the felling cost is higher than that of Grulois's study.

\section{CONCLUSION AND IMPLICATION}

\section{A. Conclusion}

1. The average tree damage caused by lowest possible felling technique is $2.96 \%$ less than that by conventional felling technique.

2. Poles damage due to tree felling using lowest possible felling technique is $4.75 \%$ less than that using conventional felling technique.

3. In lowest possible felling technique, the felling productivity is $17.16 \%$ less than in conventional felling technique. It is caused by the fact that the preparation of back and felling cut of lowest possible felling technique requires more time as it has to be prepared precisely.

4. Physically, the volume of timber collected using lowest possible felling technique is higher than that using conventional felling. In this case, the felling efficiency of lowest possible felling technique is $3.2 \%$ higher than that of conventional technique.

5. In lowest possible felling technique, the felling cost is more expensive $\mathrm{Rp} 327.07 / \mathrm{m}^{3}$ than that in conventional technique. It is caused by the fact that during study, the chain saw operator has not been familiar with the lowest possible felling technique.

6. The stump height left in the field by using lowest possible felling technique is lower than that using conventional felling. This means using lowest possible felling technique can reduce felling waste that usually left by conventional felling technique.

\section{B. Implication}

The result of this research has given an opportunity for logging concession holder to improve felling technique in logging concession area. This improvement can add value to logging processing and also save forest's natural resource. It would be better if the logging concession company implement the lowest possible felling technique. 


\section{REFERENCES}

Grulois, S. 2000. Economic cost assessment of reduced impact logging in Bulungan research site (East Kalimantan). CIFOR Final Report (Unpublished).

Holmes, T.P., G.M. Blese, J.C. Zweede, R. Pereira, P. Bareto, F. Boltz and R. Bouch. 1999. Financial cost and benefits of reduced impact logging relative to conventional logging in Eastern Amazone. Final Report, Tropical Forest Foundation, USDA Forest Service (Unpublished).

Prajitno, D. 1981. Analisa Regresi dan Korelasi untuk Penelitian Pertanian. Liberty, Yogyakarta.

Suhartana, S. 2001. Pengaruh penebangan terkendali dan konvensional terhadap kerusakan tegakan tinggal dan produktivitas kerja. Buletin Penelitian Hasil Hutan 19(4):219-230. Pusat Penelitian dan Pengembangan Teknologi Hasil Hutan, Bogor.

Welburn, G.U. 1981. Logging in mountainous regions. Proceeding of XVII IUFRO Congress Committee, Ibaiki. 